\title{
PENERAPAN MODEL PEMBELAJARAN KOOPERATIF TIPE INVESTIGATION DENGAN PENDEKATAN OPEN ENDED PROBLEM UNTUK MENINGKATKAN KEMAMPUAN REPRESENTASI MATEMATIS
}

\author{
La Ode Sirad $^{1 *}$, Gemi Susanti ${ }^{2}$, Rasidahtul Adawiah ${ }^{3}$ \\ 1,2,3Prodi Pendidikan Matematika Fakultas Keguruan dan Ilmu Pendidikan, USN Kolaka \\ J1. Pemuda No. 399, Kolaka, Kabupaten Kolaka, Sulawesi Tenggara 93517, Indonesia \\ e-mail: ${ }^{1}$ laodesirad.usnkolaka@gmail.com;
}

corresponding author*

\begin{abstract}
Abstrak
Tujuan penelitian ini adalah untuk meningkatkan kemampuan representasi matematis siswa kelas VIII ${ }^{2}$ SMP Negeri 3 Raha Tahun Pelajaran 2018/2019 selama kegiatan pembelajaran matematika dengan penerapan model pembelajaran kooperatif tipe group investigation dengan pendekatan open ended problem. Jenis penelitian ini adalah penelitian tindakan kelas yang terdiri dari dua siklus yang didasarkan pada silabus pengajaran guru matematika pada kelas VIII ${ }^{2}$ SMP Negeri 3 Raha. Setiap siklus dilaksanakan berdasarkan standar kompetensi yang ingin di capai dalam pembelajaran. Siklus dalam penelitian tindakan kelas ini dengan melalui empat tahap yaitu: rencana tindakan, pelaksanaan tindakan, observasi dan refleksi. Berdasarkan hasil penelitian yang dilaksanakan pada siswa kelas VIII ${ }^{2}$ SMP Negeri 3 Raha Tahun Pelajaran 2018/2019 pada standar kompetensi menghitung luas dan volume dari prisma dan limas menggunakan model pembelajaran kooperatif tipe group investigation dengan pendekatan open ended problem dapat meningkatkan kemampuan representasi matematis, yaitu : respon dan hasil belajar yang ditunjukkan siswa pada siklus II tergolong sangat baik, dan nilai tes kemampuan representasi matematis siswa pada setiap siklus mengalami peningkatan dengan baik, hingga pada siklus terakhir menunjukkan hasil $80 \%$. Berdasarkan hasil tes terlihat bahwa hanya terdapat 4 siswa dari total 20 siswa yang memiliki nilai dibawah 68 yang merupakan standar nilai kriteria ketuntasan yang ditetapkan oleh sekolah. Aktivitas siswa dan pengelolaan pembelajaran oleh guru dalam proses pembelajaran juga mengalami peningkatan hingga pada siklus II mencapai rata-rata $82 \%$ dan $81 \%$. Dengan demikian pembelajaran dengan menerapkan model pembelajaran kooperatif tipe group investigation dengan pendekatan open ended problem dapat meningkatkan kemampuan representasi matematis.
\end{abstract}

Kata Kunci: group investigation, open ended problem, representasi matematis

\section{IMPLEMENTATION OF INVESTIGATION COOPERATIVE MODEL USING OPEN ENDED APPROACH TO IMPROVE MATHEMATICS REPRESENTATION ABITILY}

\begin{abstract}
The purpose of this research is to improve the ability of mathematical representation of Grade VIII ${ }^{2}$ students at SMP Negeri 3 Raha 2018/2019 Academic Year during mathematics learning activities with the application of cooperative learning model in the type group investigation with open ended problem approach. The type of research is classroom researh of two cycles based on teaching syllabus of the mathematics teacher in class $\mathrm{VIII}^{2}$. Each cycle is carried ot based on the competency standards to be achieved in learning. The cycle in this class action research through four stages, namely: planning of action; implementation of action; observation and evaluation; reflection. Based on the result of research conducted on the Grade VIII ${ }^{2}$ students at SMP Negeri 3 Raha 2018/2019 Academic Year on the competency standards: calculating area and volume of prism and pyramid using cooperative learning model in the type group investigation with open ended problem approach can improve the ability of mathematical representation, which are : respones and learning outcomes shown in cycle II are primly goodand the students scoreof
\end{abstract}

Copyright ( $\odot$ Authors. This is an open access article distributed under the Attribution-NonCommercialShareAlike 4.0 International (CC BY-NC-SA 4.0), which permits unrestricted use, distribution, and reproduction in any medium, provided the original work is properly cited. 
mathematical representation test capability in each cycle has improve signivicantly, until $80 \%$ on the last cycle. Moreover, the results showed that there are only 4 students from total 20 students who obtain score 68 which is the minimum completeness criteria set by the school. Student activities and learning management by the teacher in the learning process also increased to cycle II reaching an average of $82 \%$ and $81 \%$. Therefore, learning by applying cooperative learning model in the type group investigation with open ended problem approach can improve the ability of mathematical representation.

Keywords: group investigation, mathematical representation, open ended problem

\section{Pendahuluan}

Program pendidikan matematika yang merupakan salah satu upaya untuk memenuhi tujuan menurut Peraturan Menteri Pendidikan Nasional (Permendiknas) Nomor 22 Tahun 2006 tentang Standar Isi Mata Pelajaran Matematika untuk semua jenjang pendidikan dasar dan menengah menyatakan bahwa tujuan mata pelajaran matematika di sekolah adalah agar siswa mampu memahami konsep matematika, menjelaskan keterkaitan antar konsep atau algoritma, secara luwes, akurat, efisien dan tepat dalam pemecahan masalah (Tristiyati \& Afriansyah, 2016). Adapun berdasarkan Peraturan Menteri Pendidikan dan Kebudayaan Nomor 103 Tahun 2014 menyatakan tujuan pendidikan matematika yaitu agar peserta didik memiliki kemampuan mengkomunikasikan gagasan dengan simbol, tabel, diagram, atau media lain untuk memperjelas keadaan atau masalah (Depdikbud, 2014)

\section{National Council of Theacher of} Mathematics (NCTM) atau Dewan Nasional Guru Matematika menetapkan lima standar kemampuan matematis yang harus dimiliki oleh siswa, yaitu: kemampuan pemecahan masalah, kemampuan komunikasi, kemampuan koneksi, kemampuan penalaran, dan kemampuan representasi. Kemampuan matematis yang perlu dikembangkan diantaranya adalah kemampuan representasi matematis. Kemampuan representasi matematis merupakan salah satu hal yang sangat penting dalam pembelajaran matematika. Selain itu, representasi merupakan dasar bagaimana seseorang menggunakan dan memahami ide atau gagasan dalam memecahkan masalah. Representasi dapat berupa diagram, tampilan grafik, dan simbol. Representasi adalah alat berpikir yang kuat, namun bagi banyak siswa, kekuatan ini tidak dapat diakses kecuali siswa menerima bimbingan terarah dalam mengembangkankan kemampuan siswa (NCTM, 2000). Kemampuan representasi penting bagi siswa dalam belajar matematika, karena dengan representasi siswa dapat mengemukakan hal-hal abstrak dari matematika ke dalam bahasa lain, simbol tertulis, dan gambar (Sabirin, 2014).
Kemampuan representasi merupakan salah satu kompetensi yang selalu harus ada dalam pembelajaran matematika.

Hudiono menyatakan bahwa kemampuan representasi tidak hanya membahas terbatas pada penggunaan notasi simbol untuk menerjemahkan suatu situasi ke langkah matematika. Representasi lebih dari sekedar produk fisik hasil observasi. Representasi juga merupakan proses kognitif yang terjadi secara internal. Representasi adalah suatu aktivitas interpetasi konsep atau masalah dengan memberikan makna (Sabirin, 2014:82). Representasi akan menolong peserta didik untuk mengatur proses berpikirnya. Representasi berguna untuk membantu menyusun ide-ide matematika lebih kongkrit dan nyata untuk bahan pemikiran (Dahlan dan Juandi, 2011:130). Lesh, Post dan Behr membagi lima representasi yang digunakan dalam pembelajaran matematika. Meliputi representasi objek dunia nyata, representasi konkret, representasi simbol aritmetika, representasi bahasa lisan atau verbal dan representasi gambar atau grafik. Di antara kelima representasi tersebut, tiga yang terakhir lebih abstrak dan merupakan tingkat representasi yang lebih tinggi dalam memecahkan masalah matematika (Dahlan dan Juandi, 2011:132).

Berdasarkan hasil wawancara yang dilakukan peneliti dengan guru matematika kelas VIII $^{2}$ di SMP Negeri 3 Raha Tahun Ajaran 2018/2019, diketahui bahwa kemampuan representasi siswa masih rendah. Hal ini disebabkan, diantaranya pada saat proses pembelajaran berlangsung siswa cenderung hanya mengikuti pola yang diberikan oleh guru, jarang dari siswa yang menuangkan ide dengan bahasa atau kalimat sendiri. Siswa mengalami kesulitan ketika menyampaikan pendapat baik secara lisan maupun tulisan. Siswa kurang mampu untuk menjelaskan arti suatu grafik atau gambar dalam konteks masalah kehidupan sehari-hari yang bersifat abstrak. Indikator-indikator tersebut menunjukan bahwa kemampuan representasi matematis di kelas VIII $^{2}$ SMP Negeri 3 Raha tergolong rendah. Hal di atas juga ditunjukkan dengan nilai rata-rata ulangan harian siswa yaitu 59,85 pada standar kompetensi menghitung luas 
dan volume kubus dan balok yang keseluruhan soal ulangan harian materi tersebut terkait dengan indikator kemampuan representasi yang tidak mencapai Kriteria Ketuntasan Minimum yaitu 68.

Selain itu jika dilihat lebih lanjut, penyebab lain rendahnya kemampuan representasi matematis siswa terletak pada model pembelajaran, pendekatan pembelajaran atau penggunaan strategi, metode, teknik mengajar yang belum tepat. Pembelajaran yang sering digunakan guru pada umumnya masih konvensional yaitu pembelajaran yang masih terpusat pada guru sehingga kurang efektif dalam meningkatkan kemampuan representasi matematis siswa. Berdasarkan kondisi yang telah dijelaskan di atas, muncul pertanyaan mengenai model, pendekatan, atau strategi apa yang cocok untuk diterapakan agar mampu mendukung upaya peningkatan kemampuan representasi matematis siswa kelas VIII2 SMPN 3 Raha Tahun Ajaran 2018/2019 dengan melibatkan siswa secara maksimal.

Berdasarkan penjelasan dan permasalahan tersebut, peneliti mencoba menghadirkan model pembelajaran kooperatif tipe group investigation dengan menggunakan pendekatan open ended problem yang dapat mewujudkan tujuan dalam penelitian ini yaitu meningkatkan kemampuan representasi matematis siswa kelas VIII ${ }^{2}$ SMPN 3 Raha Tahun Ajaran 2018 / 2019 pada standar kompetensi meghitung luas dan volume prisma dan limas. Model pembelajaran kooperatif tipe group investigation dengan pendekatan open-ended problem berdasarkan hasil wawancara dengan guru matematika kelas VIII ${ }^{2}$ SMPN 3 Raha merupakan hal yang baru untuk dilaksanakan dalam pembelajaran matematika sehingga dalam pelaksanaannya masih memiliki kendala. Kendalakendala tersebut diantaranya siswa belum terbiasa dalam kerja kelompok dan siswa belum terbiasa menyelesaikan masalah matematika dalam bentuk masalah terbuka atau open ended problem.

Sebuah metode investigasi kooperatif dari pembelajaran di kelas diperoleh dari premis bahwa baik dominan sosial maupun intelektual proses pembelajaran sekolah melibatkan nilai-nilai yang didukungnya. Group investigation tidak akan dapat diimplementasikan dalam lingkungan pendidikan yang tidak mendukung dialog interpersonal atau yang tidak memperhatikan dimensi rasa sosial dari pembelajaran di dalam kelas. Komunikasi dan interaksi kooperatif di antara teman sekelas akan mencapai hasil terbaik apabila dilakukan dalam kelompok kecil, dimana pertukaran di antara teman sekelas dan sikap-sikap kooperatif terus bertahan. Aspek rasa sosial dari kelompok, pertukaran intelektualnya, dan maksud dari subyek yang berkaitan dengannya dapat bertindak sebagai sumber penting bagi usaha siswa untuk belajar (Sutikno, 2014:130). Metode investigasi kelompok sering dipandang sebagai metode yang paling kompleks dan paling sulit untuk dilaksanakan dalam pembelajaran kooperatif. Para guru yang menggunakan metode investigasi kelompok umumnya membagi kelas menjadi beberapa kelompok dengan karakteristik yang heterogen. Pembagian kelompok dapat juga didasarkan atas kesenangan berteman atau kesamaan minat terhadap suatu topik tertentu. Para siswa memilih topik yang ingin dipelajari, mengikuti investigasi mendalam terhadap berbagai subtopik yang telah dipilih, kemudian menyiapkan dan menyajikan suatu laporan di depan kelas secara keseluruhan (Agus, 2015:112).

Untuk lebih meningkatkan kemampuan representasi matematis maka model pembelajaran kooperatif tipe group investigation dikolaborasikan dengan pendekatan open ended problem. Pendekatan pembelajaran open-ended merupakan pendekatan pembelajaran yang menggunakan masalah open-ended. Kegiatan pembelajaran dengan pendekatan open-ended harus mempertimbangkan tiga karakteristik, yaitu: (a) kegiatan belajar siswa harus bersifat terbuka; (b) kegiatan matematika adalah keragaman berpikir; dan (c) kegiatan siswa dan kegiatan matematik merupakan satu kesatuan (Arifin, 2011:120). Tujuan pembelajaran dengan pendekatan openended adalah membantu siswa dalam mengembangkan kreativitas dan pola pikir matematis melalui kegiatan pemecahan masalah secara simultan. Kreativitas dan pola pikir matematis ini harus dikembangkan dengan memperhatikan kemampuan berpikir setiap siswa. Aktivitas pembelajaran yang memberikan peluang bagi siswa untuk mengemukakan gagasannya secara bebas akan mamacu peningkatan kemampuan berpikir yang lebih tinggi (High Order Thinking) (Arifin, 2011:119).

Berdasarkan uraian tersebut, beberapa alasan peneliti memilih model pembelajaran group investigation dengan pendekatan open ended problem adalah sebagai berikut; (1) dalam model pembelajaran ini siswa harus dapat memfokuskan pikiran terhadap suatu permasalahan yang menjadi bahan untuk investigasi; (2) dalam model pembelajaran ini siswa dituntut untuk dapat menganalisis dan memecahkan suatu pokok permasalahan dari berbagai sumber informasi, baik dari dalam maupun dari luar lingkungan sekolah; (3) model pembelajaran ini dapat membantu siswa untuk dapat bekerja sama dengan baik, saling berdiskusi, dan memecahkan masalah bersama- 
sama; (4) model pembelajaran ini dapat menimbulkan respon positif dari siswa untuk mengerjakan tugas akhir yang diberikan sebagai evaluasi. Secara sederhana kerangka proses pembelajaran digambarkan dalam bentuk prosedur kerangka pemikiran sebagai berikut:

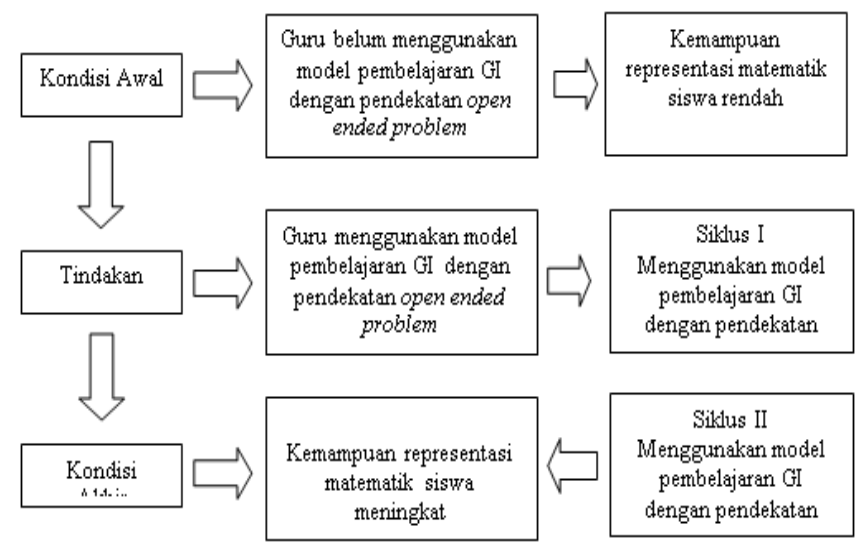

Gambar 1. Bagan Kerangka Pemikiran

\section{Metode Penelitian}

Penelitian ini adalah Penelitian Tindakan Kelas (Classroom Action Research). Penelitian Tindakan Kelas merupakan suatu pencermatan terhadap kegiatan belajar berupa sebuah tindakan, yang sengaja dimunculkan dan terjadi didalam kelas secara bersama. Oleh karena itu, peneliti mengunakan jenis Penelitian Tindakan Kelas (PTK) dengan menerapkan model pembelajaran Group Investiagtion dirangkaikan dengan pendekatan open ended problem.

Jenis penelitian tindakan kelas yang peneliti gunakan yaitu penelitian tindakan kelas kolaborasi. Kolaborasi adalah adanya kerjasama antara berbagai disiplin ilmu, keahlian dan profesi dalam memecahkan masalah, merencanakan, melaksanakan kegiatan dan melakukan penilaian akhir (Mulyasa, 2013:152). Kolaborasi anatar guru, kepala sekolah, siswa dan peneliti menjadi hal penting dalam pelaksanaan tindakan kelas (PTK) sebab salah satu ciri khas PTK adalah adanya kolaborasi atau kerjasama antara praktisi dan peneliti dalam pemahaman, kesepakatan tentang permasalahan, pengambilan keputusan yang akhirnya melahirkan tindakan (action) (Arikunto, 2013:63). Penelitian ini dilaksanakan di kelas VIII ${ }^{2}$ SMP Negeri 3 Raha pada semester genap Tahun Ajaran 2018/2019 yang beralamat di Kecamatan Katobu Kabupaten Muna. Subjek penelitian ini adalah siswa kelas VIII ${ }^{2}$ SMP Negeri 3 Raha Kabupaten Muna Tahun Pelajaran 2018/2019 dengan jumlah 20 siswa.

Teknik pengumpulan data yang digunakan yaitu: 1) Data mengenai tes kemampuan representasi matematis diambil dengan memberikan tes formatif pada setiap akhir siklus, 2) Data mengenai kinerja guru dalam pembelajaran diambil dari lembar observasi guru, digunakan untuk memperoleh data yang memperlihatkan pengelolaan pembelajaran matematika melalui model pembelajaran kooperatif tipe Group Investigation (GI) dengan menggunakan pendekatan open ended problem dengan bantuan LKS oleh guru, 3) Data mengenai kinerja siswa dalam pembelajaran diambil dari lembar observasi siswa, digunakan untuk memperoleh data yang dapat memperlihatkan aktivitas siswa selama pembelajaran matematika melalui model pembelajaran kooperatif tipe Group Investigation (GI) dengan menggunakan pendekatan open ended problem.

Penelitian tindakan kelas ini dilaksanakan terdiri dari 2 siklus yang didasarkan pada silabus pengajaran guru matematika pada kelas VIII ${ }^{2}$. Tiap siklus dilaksanakan berdasarkan tujuan yang ingin di capai dalam proses pembelajaran. Sebelum pelaksanaan tindakan kelas, terlebih dahulu dilaksanakan observasi pembelajaran matematika dan wawancara terhadap guru matematika kelas VIII $^{2}$. Siklus dalam penelitian tindakan kelas ini adalah sebagai berikut:

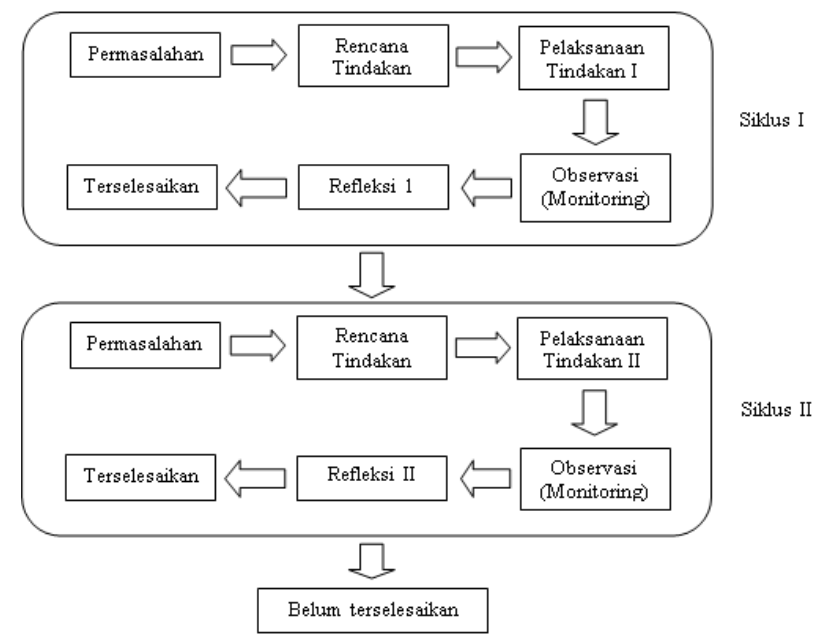

Gambar 2. Desain Penelitian Tindakan Model Kemmis dan Mc Taggar (Yuliawati dkk, 2014: 24)

\section{Siklus I}

a. Rencana Tindakan

Pada tahap ini materi pokok yang disiapkan adalah bangun ruang sisi datar dengan kompetensi dasar menyelesaikan masalah open ended yang berkaitan dengan menghitung luas permukaan dan volume bangun ruang prisma dan limas. Hal-hal yang direncanakan adalah Menyiapkan rencana pelaksanaan pembelajaran (RPP) dengan memilih model pembelajaran kooperatif tipe 
Group Investigation (GI) dengan pendekatan open ended problem sebagai metode pembelajaran; Menyiapkan lembar kerja siswa (LKS) untuk menyelesaikan masalah kontekstual yang berkaitan dengan menghitung luas permukaan dan volume bangun ruang prisma dan limas ; Membuat lembar observasi untuk mengamati keaktifan siswa selama pembelajaran berlangsung dan lembar observasi untuk guru ; Mempersiapkan soal yang di berikan pada setiap akhir siklus.

b. Pelaksanaan Tindakan

Pada tahap pelaksanaan guru melaksanakan rancangan pembelajaran matematika denga menggunakan strategi pembelajaran kooperatif tipe Group Investgation (GI) dengan menggunakan pendekatan open ended problem berdasarkaan RPP yang telah di persiapkan. Adapun tindakan pada siklus I dilaksanakan dalam 3 (tiga) kali pertemuan yaitu: 1) Pertemuan pertama: Pelaksanaan pembelajaran ; Instrumen yang digunakan meliputi: Rencana Pelaksanaan Pembelajaran (RPP), Lembar Kerja Siswa (LKS), Soal-soal, Lembar observasi untuk guru dan siswa; dan Pokokpokok materi, 2) Pertemuan Kedua: Pelaksanaan pembelajaran ; Instrumen yang digunakan meliputi: Rencana Pelaksanaan Pembelajaran (RPP), Lembar Kerja Siswa (LKS), Soal-soal, Lembar observasi untuk guru dan siswa ; Pokok-pokok materi, 3) Pertemuan ketiga: Mengadakan evaluasi siklus I. Evaluasi atau tes tindakan siklus I dengan memberikan soal-soal yang berbentuk open ended problem untuk melihat peningkatan kemampuan representasi matematis siswa terhadap materi pelajaran setelah model pembelajaran kooperatif tipe group investigation diterapkan.

c. Observasi dan Evaluasi

Pengamatan dilakukan untuk mengetahui peningkatan kemampuan representasi matematis siswa melalui model pembelajaran tipe group investigation dengan pendekatan open ended problem. Kemampuan representasi matematis siswa yang diamati meliputi tiga indikator, yaitu: (1) Representasi berupa gambar, (2) Representasi berupa ekspresi matematis, (3) Representasi berupa teks tertulis. Peneliti mengamati kemampuan representasi matematis siswa setelah melakukan evaluasi dengan memberikan masalah matematika yang berbentuk open ended problem pada standar kompetensi menghitung luas bangun ruang prisma dan limas yang sudah dibuat oleh peneliti. Melalui tes tindakan siklus I ini juga bertujuan untuk melatih siswa lebih bertanggung jawab secara individual terhadap kemampuan representasi matematisnya. Nlai tes menunjukkan bahwa kemampuan representasi matematis siswa terhadap materi pelajaran mengalami peningkatan dari nilai awal. Siswa yang memperoleh nilai $\geq 68$ sebanyak 10 orang sebesar 50\% dengan nilai rata-rata 64,08. Rendahnya kemampuan representasi matematis siswa ini khususnya pada indikator representasi berupa gambar dengan persentase 54,16 dan persamaan atau ekspresi matematis dengan persentase 41,56.

Hasil pengamatan terhadap model pembelajaran yang diterapkan, peneliti menilai siswa belum memahami secara jelas tujuan belajar secara kooperatif yang mengutamakan kebersamaan dalam kerja kelompok, keterbukaan, komunikasi, kemauan dalam membantu teman dan kemampuan berperan lebih aktif dalam kelompok. Di samping itu siswa belajar untuk saling menghargai dalam hidup berdampingan satu sama lain, sehingga kebersamaan betul-betul terjalin dan akhirnya kegiatan tidak didominasi oleh satu siswa tertentu saja terutama siswa yang hanya gemar matematika. Siswa juga belum memahamai proses penyelesaian masalah matematika dalam bentuk masalah terbuka. Siswa merasa bingung jika diberikan masalah dalam bentuk open ended problem.

d. Refleksi

Setelah proses pembelajaran dan evaluasi kemampuan representasi matematis siswa dilaksanakan pada siklus I, peneliti bersama guru secara kolaboratif menilai dan mendiskusikan kelemahan-kelemahan dan kekurangan yang terdapat pada pelaksanaan tindakan siklus I. Pada pelaksanaan siklus I dengan standar kompetensi menghitung luas bangun ruang prisma dan limas ini diperoleh hasil pembelajaran yang belum memenuhi indikator keberhasilan pembelajaran, ini berkaiatan dengan peneliti maupun dengan siswa. Berkaiatan dengan peneliti : peneliti tidak terlibat dalam pemilihan kelompok, peneliti masih kurang jelas dalam hal menjelaskan materi pembelajaran dengan pendekatan open ended problem, penenliti kurang memotivasi siswa dalam menyelesaikan masalah matematika yang berbentuk open ended problem. Dari segi siswa : siswa masih merasa baru atau belum 
terbiasa dengan penerapan metode pembelajaran yang diterapkan oleh guru, terdapat kelompok yang ribut saat peneliti menjelaskan materi pembelajaran, siswa belum terbiasa menyelesaiakan persoalan matematika ang berbentuk open ended problem.Dari hasil refleksi diatas, peneliti bersama guru secara kolaboratif akan melakukan tindakan kembali yaitu melakukan penelitian pada siklus II.

\section{Siklus I}

Tahap kegiatan pembelajaran pada siklus II mengikuti tahap kegiatan siklus I. Dalam hal ini, rencana tindakan siklus ke II disusun berdasarkan hasil refleksi pada siklus I. Kegiatan-kegiatan yang dilakukan pada siklus II dimaksudkan sebagai penyempurnaan atau perbaikan terhadap pelaksanaan pembelajaran matematika dengan model pembelajaran kooperatif tipe Group Investigation (GI) dengan menggunakan pendekatan open ended problem pada siklus I. Berdasarkan hasil observasi, evaluasi dan refleksi yang telah dilakukan pada siklus I, maka peneliti merencanakan tindakan siklus II untuk mengatasi dan memperbaiki kelemahan-kelemahan yang terjadi pada pelaksanaan pembelajaan siklus I, sehingga akan diperoleh pembelajaran yang lebih baik. Secara sistematis, beberapa perbaikan yang perlu dilakukan pada siklus II, antara lain : Peninjauan kembali RPP, simulasi dan diskusi kegiatan pembelajaran, pelaksanaan pembelajaran dilaksanakan sesuai skenario yang telah disusun dan dilakukan bersamaan dengan kegiatan observasi belajar siswa untuk menganalisis efektifitas perangkat pembelajaran yang dikembangkan. Melakukan tes pada akhir pembelajaran untuk menilai hasil belajar untuk melihat kemampuan representasi matematik siswa. Mengevaluasi kegiatan pembelajaran yang selanjutnya dilakukan refleksi untuk menganalisis sejauh mana penerapan model pembelajaran kooperatif tipe Group Investigation (GI) dengan menggunakan pendekatan open ended problem terhadap peningkatan kemampuan peningkatan kemapuan representasi matematik siswa.

Setelah diadakannya tindakan siklus II dengan menerapakan model pembelajaran kooperatif tipe group investigation dengan pendekatan open ended problem pada standar kompetensi menghitung volume bangun ruang prisma dan limas, nilai rata-rata kemampuan representasi matematis siswa meningkat dan ketuntasan untuk setiap indikator kemampuan representasi matematis sudah mencapai hasil yang memuaskan terutama pada indikator representasi berupa ekspresi matematis dan representasi berupa teks tertulis dari jumlah siswa yang memperoleh nilai $>68$ yaitu 16 orang atau ketuntasan belajar sebesar $80 \%$. Hal yang diperoleh pada siklus 2 setelah menerapkan model pembelajaran kooperatif tipe group investigation dengan pendekatan open ended problem yaitu : siswa aktif sudah mulai aktif dalam proses pembelajaran baik dalam kelompok maupun secara klasikal, berani menyampaikan ide-ide dalam penyelesaian masalah matematika berupa open ended, siswa sudah mampu memperesentasikan hasil diskusinya. Namun ada beberapa siswa hanya terdiam jika hanya diberi kesempatan bertanya

\section{Hasil dan Pembahasan}

\subsection{Hasil}

Berdasarkan hasil wawancara dan tes kemampuan representasi matematis siswa kelas VIII $^{2}$ SMP Negeri 3 Raha pada standar kompetensi menghitung luas dan volume bangun ruang prisma dan limas memiliki hasil yang berbeda untuk setiap siklus pembelajaran. Hasil tes pada masing-masing siklus untuk setiap pertemuan menggambarkan pencapaian indikator kemampaun representasi matematik siswa yang berbeda-beda. Nilai tes menunjukkan bahwa kemampuan representasi matematis siswa terhadap materi pelajaran mengalami peningkatan dari nilai awal. Siswa yang memperoleh nilai $\geq 68$ sebanyak 10 orang sebesar $50 \%$ dengan nilai rata-rata 64,08. Hasil selengkapnya dapat dilihat pada tabel 1 berikut.

Tabel 1. Perolehan Nilai Rata-rata dan Persentase Ketuntasan pada Tes Tindakan Siklus I

\begin{tabular}{lc}
\hline \multicolumn{1}{c}{ Nilai } & Tes Tindakan Siklus 1 \\
\hline Rata-rata & 64,08 \\
Ketuntasan Klasikal & $50 \%$ \\
Keterangan & Tidak Tuntas \\
\hline
\end{tabular}

Dari tabel diatas menunjukkan bahwa keberhasilan penerapan model pembelajaran kooperatif tipe group investigation dengan pendekatan open ended problem belum mencapai kriteria keberhasilan dalam penelitian. Presentasi nilai tes hasil kemampuan representasi matematik siswa pada siklus I hanya menncapai 50\%, sedangkan 10 orang siswa masih memperoleh nilai dibawah 68 .

Nilai tes menunjukkan bahwa kemampuan representasi matematis siswa terhadap materi pelajaran mengalami peningkatan dari tes siklus I. Siswa yang memperoleh nilai $\geq 68$ sebanyak 16 orang persentase sebesar $80 \%$ dengan nilai ratarata 73,98 dalam hal ini mengalami peningkatan 
sebesar 30\% hasil tes tindakan siklus II. hasil selengkapnya dapat dilihat pada tabel 2 berikut:

Tabel 2. Perolehan Nilai Rata-rata dan Persentase Ketuntasan pada Tes Tndakan Siklus II

\begin{tabular}{lc}
\hline \multicolumn{1}{c}{ Nilai } & Tes Tindakan Siklus 1 \\
\hline Rata-rata & 73,98 \\
Ketuntasan Klasikal & $80 \%$ \\
Keterangan & Tuntas \\
\hline
\end{tabular}

Berdasarkan analisis pada tes hasil siklus II terlihat bahwa penerapan model pembelajaran kooperatif tipe group investigation dengan pendekatan open ended problem pada pembelajaran siklus II telah diperoleh nilai yang memenuhi indikator pembelajaran dalam penelitian ini. Presentasi nilai tes kemampuan representasi matematis siswa pada siklus II telah mencapai $80 \%$, dimana siswa yang mendapat nilai di bawah 75 hanya 4 siswa dari 20 siswa.

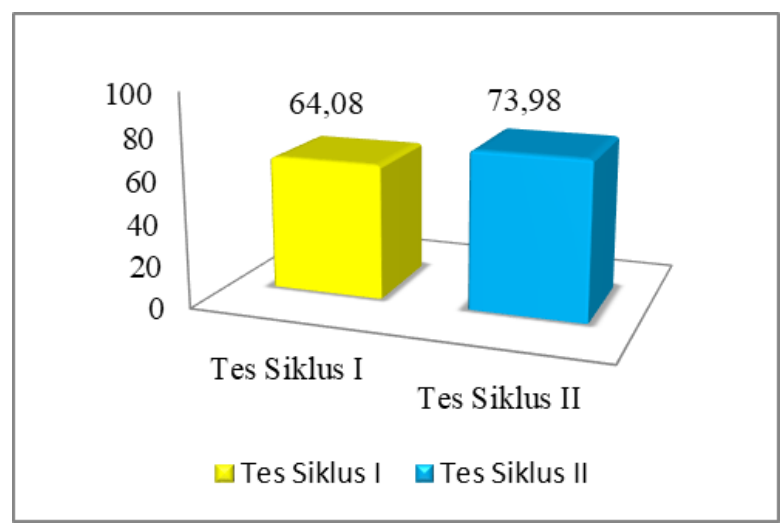

Gambar 3. Rata-Rata Kemampuan Representasi Matematis Siswa

\section{Aktivitas Siswa Dalam Pembelajaran}

Indikator-indikator yang dinilai dalam pembelajaran matematika dengan menggunakan model pembelajaran kooperatif tipe group investigation dengan pendekatan open ended problem pada standar kompetensi menghitung luas dan volume bangun ruang prisma dan limas meliputi: perhatian siswa, diskusi kelompok, pengerjaan tugas/LKS, bertanya dan presentasi. Dalam setiap pertemuan dalam dua siklus tersebut siswa mengalami peningkatan aktivitas belajar. Pada pertemuan awal mungkin saja belum bisa menyesuaikan dengan pendekatan pembelajaran yang digunakan, dikarenakan model pembelajaran dan pendekatan ini baru pertama kali dilaksanakan di kelas VIII ${ }^{2}$ SMP Negeri 3 Raha.

Tabel 3. Perolehan Nilai Persentase Aktivitas Siswa Tindakan Siklus I

\begin{tabular}{lcc}
\hline \multirow{2}{*}{ Nilai } & \multicolumn{2}{c}{ Siklus 1 } \\
\cline { 2 - 3 } & Pertemuan 1 & Pertemuan 2 \\
\hline Skor & 21 & 25
\end{tabular}

\begin{tabular}{lcc} 
Persentase & $52 \%$ & $62 \%$ \\
\hline Rata-rata & \multicolumn{3}{c}{$57 \%$} \\
\hline
\end{tabular}

Berdasarkan analisis perolehan nilai persentase aktivitas siswa pada tindakan siklus I terlihat bahwa presentase aktivitas siswa pada hasil observasi siswa siklus I pertemuan I adalah 52\% dan persentase aktivitas siswa siklus I pertemuan 2 adalah $62 \%$. Rata-rata hasil observasi pada siklus I yaitu $57 \%$ dan belum mencapai ketuntasan yang ditetapkan sebelumnya yaitu $80 \%$. Jadi, perlu perbaikan dalam pelaksanaan proses pembelajaran yang akan dilaksanakan pada tindakan siklus II.

Tabel 4. Perolehan Nilai Persentase Aktivitas Siswa Tindakan Siklus II

\begin{tabular}{lcc}
\hline \multirow{2}{*}{ Nilai } & \multicolumn{2}{c}{ Siklus 1I } \\
\cline { 2 - 3 } & Pertemuan 1 & Pertemuan 2 \\
\hline Skor & 31 & 35 \\
Persentase & $77 \%$ & $87 \%$ \\
\hline Rata-rata & \multicolumn{2}{c}{$82 \%$} \\
\hline
\end{tabular}

Berdasarkan analisis perolehan nilai persentase aktivitas siswa pada tindakan siklus II terlihat bahwa bahwa persentase aktivitas siswa pada hasil observasi siswa siklus II pertemuan I adalah $77 \%$ dan persentase aktivitas siswa siklus II pertemuan 2 adalah $87 \%$. Rata-rata hasil observasi pada siklus II yaitu $82 \%$ dan sudah mencapai ketuntasan yang ditetapkan sebelumnya yaitu $80 \%$.

Dari hasil refleksi pada pengamatan selama siklus I pertemuan 1 menunjukkan keaktifan siswa dalam mengikuti pembelajaran sebesar 52\%, siklus I pertemuan 2 sebesar 62\%. Selanjutnya pengamatan keaktifan siswa selama berlangsungya siklus II mengalami peningkatan sebesar $77 \%$ pada pertemuan 1 siklus II dan $87 \%$ untuk pertemuan 2 siklus II. Hasil selengkapnya dapat dilihat pada gambar 3 berikut:

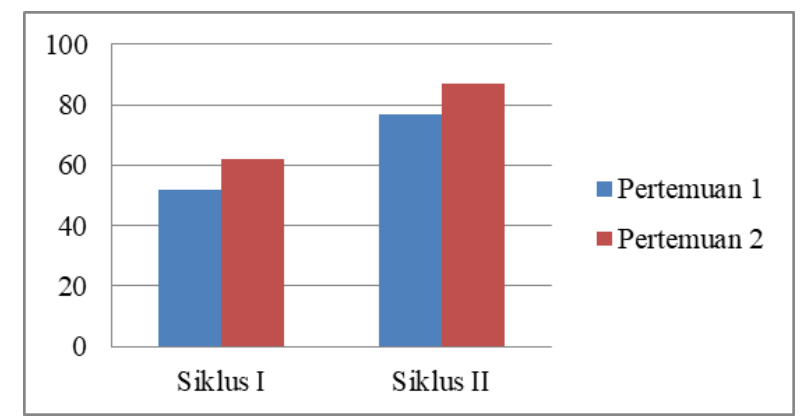

Gambar 4. Presentase Keaktifan Siswa

\section{Aktivitas Guru Dalam Mengelolah Pembelajaran}

Dalam hal pengelolaan pembelajaran yang dilakukan oleh guru, dalam setiap pertemuan dalam dua siklus tersebut kinerja guru dalam proses pembelajaran mengalami peningkatan. 
Walaupun pada siklus I bahwa kemampuan guru dalam mengelola pembelajaran pada siklus I ini adalah tergolong belum efektif. Tetapi pada siklus II kemapuan guru dalam mengelola pembelajaran pada siklus II ini adalah lebih baik dari siklus I dan tergolong efektif.

Tabel 5. Perolehan Nilai Rata-rata dan Persentase Ketuntasan Aktivitas Guru pada Tindakan Siklus I

\begin{tabular}{lcc}
\hline \multirow{2}{*}{ Nilai } & \multicolumn{2}{c}{ Siklus 1 } \\
\cline { 2 - 3 } & Pertemuan 1 & Pertemuan 2 \\
\hline Skor & 10 & 12 \\
Persentase & $62,50 \%$ & $75 \%$ \\
\hline Rata-rata & \multicolumn{2}{c}{$68,75 \%$} \\
\hline
\end{tabular}

Berdasarkan hasil analisis pada tabel diatas terlihat bahwa nilai kinerja guru pada hasil observasi guru siklus I pertemuan 1 adalah $62.5 \%$ dengan kategori cukup baik dan nilai kinerja guru pada hasil observasi guru siklus I pertemuan 2 adalah 75\% dengan kategori baik. Rata-rata hasil observasi guru pada siklus I yaitu $68,75 \%$ dan belum mencapai ketuntasan yang telah ditetapkan sebelumnya yaitu $80 \%$. Jadi, dalam hal ini menunjukkan bahwa kemampuan guru dalam mengelola pembelajaran pada siklus I ini adalah tergolong belum efektif.

Tabel 6. Perolehan Nilai Rata-rata dan Persentase Ketuntasan Aktivitas Guru pada Tindakan Siklus II

\begin{tabular}{lcc}
\hline \multirow{2}{*}{ Nilai } & \multicolumn{2}{c}{ Siklus 1I } \\
\cline { 2 - 3 } & Pertemuan 1 & Pertemuan 2 \\
\hline Skor & 12 & 14 \\
Persentase & $75 \%$ & $87 \%$ \\
\hline Rata-rata & \multicolumn{3}{c}{$81 \%$} \\
\hline
\end{tabular}

Berdasarkan hasil analisis dari tabel diatas terlihat bahwa persentase nilai kinerja guru pad hasil observasi guru siklus II pertemuan 1 adalah $75 \%$ dengan kategori baik, dan persentase nilai kinerja guru pada hasil observasi guru siklus II pertemuan 2 adalah $87 \%$ dengan kategori sangat baik. Rata-rata hasil observasi pada siklus II yaitu $81 \%$ dan sudah mencapai ketuntasan yang ditetapkan sebelumnya yaitu $80 \%$. Hal ini menunjukkan bahwa kemampuan guru dalam mengelola pembelajaran pada siklus II ini adalah lebih baik dari siklus I dan tergolong efektif.

Hasil refleksi pada pengamatan selama siklus I pertemuan 1 menunjukkan keaktifan guru dalam melaksanakan pembelajaran sebesar $62.5 \%$, siklus I pertemuan 2 sebesar $75 \%$. Selanjutnya pengamatan keaktifan guru selama berlangsungya siklus II sebesar $75 \%$ pada pertemuan 1 siklus II dan mengalami peningkatan sebesar $87 \%$ untuk pertemuan 2 siklus II. Hasil selengkapnya dapat dilihat pada gambar 4 berikut:

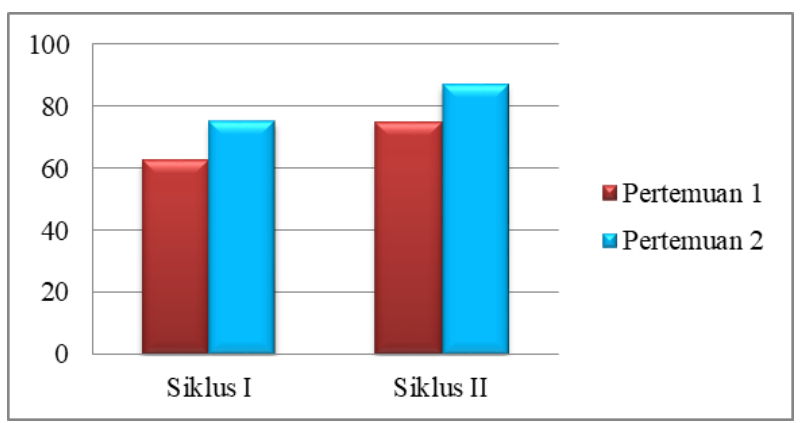

Gambar 5. Presentase Keaktifan Guru

\subsection{Pembahasan}

Penelitian tindakan kelas ini terdiri dari dua siklus. Dalam setiap siklus terdiri dari dua kali pertemuan yang dilaksanakan sesuai dengan prosedur penelitian yang telah dirancang. Banyaknya pertemuan dalam setaip siklus tergantung dari kepadatan materi yang dipelajari. Penelitian ini dilakukan di kelas VIII ${ }^{2}$ SMP Negeri 3 Raha Kab. Muna dengan menerapkan model pembelajaran kooperatif tipe group investigation dengan pendekatan open ended problem.

Penelitian ini diawali dengan kegiatan wawancara awal dengan guru bidang studi matematika kelas $\mathrm{VIII}^{2}$ SMP Negeri 3 Raha dan observasi awal pada hari Rabu tanggal 26 Desember 2018 sampai dengan hari Kamis 27 Desember 2018. Hasil observasi awal dan wawancara, masalah yang dialami oleh guru matematika tersebut pada intinya adalah siswa mengalami kesulitan dalam memahami konsep yang diberika oleh guru, serta guru mengalami kesulitan dalam menerapakan suatu model, strategi dan pendekatan pembelajaran yang tepat guna untuk menciptakan pembelajaran yang interaktif. Hal tersebut dapat berdampak pada hasil belajar siswa dan semangat belajar siswa. Oleh karena itu perlu adanya suatu tindakan dalam pembelajaran sehingga pemahaman konsep matematika siswa di kelas VIII ${ }^{2}$ dapat meningkat.

Setelah siklus I, yaitu dua kali pertemuan untuk menyelesaikan kompetensi dasar 'Menyelesaikan masalah matematika dengan open ended problem yang berkaiatan dengan menghitung Luas dan Volume Prisma, maka dilakukan evaluasi siklus I pada hari Jum'at tanggal 10 Mei 2019. Melalui tes tindakan siklus I ini juga bertujuan untuk melatih siswa lebih bertanggung jawab secara individual terhadap kemampuan representasi matematisnya. Hasil tes menunjukkan bahwa masih ada siswa yang belum memahami konsep materi yang diajarkan seperti 
pada indikator-indikator kemampuan representaisi viasual dan persamaan atau ekspresi matematis.

Berdasarkan penilaian terhadap hasil yang dikerjakan oleh siswa pada tes siklus I ditemukan $50 \%$ dari total 20 siswa yang memperoleh nilai diatas rata-rata 64,08. Hal ini berartti terdapat 10 siswa siswa yang telah memenuhi ketuntasan dalam belajar, dan terdapat $50 \%$ siswa atau 10 siswa lainnya memperoleh nilai di bawah rata-rata 64,08. Secara keseluruhan siswa dinilai belum cukup dalam memahami materi yang diajarkan, karena masih terdapat beberapa pengerjaan soal yang dikerjakan tidak sesuai dengan indikator kemapuan representasi matematik yang diharapkan. Hasil penelitian pada siklus I menunjukkan bahwa kemapuan representasi matematik siswa masih belum efektif.

Setelah dilaksanakan pembelajaran siklus II dengan pertemuan 2 kali dengan menyelesaikan kompetensi dasar menghitung luas dan volume limas, maka dilakukan evaluasi siklus II pada hari Sabtu, tanggal 18 Mei 2019. Tahap dilakukan untuk melihat peningkatan kemampuan representasi matematis siswa terhadap materi pelajaran setelah model pembelajaran kooperatif tipe group investigation diterapkan. Melalui tes tindakan siklus II ini juga bertujuan untuk melatih siswa lebih bertanggung jawab secara individual terhadap kemampuan representasi matematisnya.

Hasil pelaksanakan pembelajaran pada tindakan siklus II dapat dikategorikan dalam dua segi yaitu segi hasil dan segi proses. Dari segi hasil, berdasarkan penilaian dan pengamatan secara menyeluruh siswa telah mampu memahami materi dengan mencapai ketuntasan dalam belajar yaitu $80 \%$. Hasil tes menunjukkan terdapat 4 siswa dari total 20 siswa yang mendapat nilai dibawah 68 pada kelas VIII ${ }^{2}$ SMP Negeri 3 Raha. Dari segi proses, pelaksanaan skenario pembelajaran yang telah dilaksanakan oleh guru telah sesuai dengan RPP yang telah disusun dan telah mencapai indikator yang ditetapkan. Berpedoman pada rencana pelaksanan pembelajaran dan indikator kinerja dalam penelitian ini dapat disimpulkan telah tercapai.

Berdasarkan penjelasan di atas, kemampaun representasi matematis siswa dari pretes, siklus 1, siklus 2 menglami peningkatan. Sebelum model pembelajaran kooperatif tipe group investigation dengan pendekatan open ended problem kemampuan representasi siswa tergolong rendah. Sebeumnya pembelajaran dikelas hanya terpusat pada guru sehingga keterlibatan siswa dalam proses pembelajaran kurang optimal dan siswa hanya menjadi pembelajar yang pasif.
Dengan penerapan model pembelajaran kooperatif tipe group investigation dengan pendekatan open ended problem pada siklus 1 dan siklus 2 kemampuan representasi matematis siswa mengalami peningkatan yakni peningkatan representasi berupa gambar, representasi berupa ekspresi matematis, representasi berupa teks tertulis Adapun respon siswa setelah peneliti menerapkan model pembelajaran kooperatif ipe group investigation dengan pendekatan open ended problem, yaitu : aktif mendiskusikan materi pembelajaran dalam kelompoknya, muncul keaktifan dan keberanian dalam bertanya atau menanggapi, jelas dalam menyampaikan ide atau pendapat, muncul jiwa sosial dalam menyelesaikan suatu permasalahan.

Hasil yang diperoleh ini didukung Sutikno (2014 : 130) yang menyatakan bahwa model pembelajaran kooperatif tipe group investigation dapat mendukung komunikasi dan interaksi kooperatif diantara teman sekelas akan mencapai hasil terbaik apabila dilakukan dalam kelompok kecil, dimana pertukaran diantara teman sekelas dan sikap-sikap kooperatif terus bertahan. Aspek rasa sosial dari kelompok, pertukaran intelektualnya dan maksud dari subjek yang berkaitan dengannya dapat bertindak sebagai sumber penting bagi usaha siswa untuk belajar. Hal ini juga sependapat dengan Arifin (2011: 119) menyatakan bahwa tujuan pembelajaran dengan pendekatan open-ended adalah membantu siswa dalam mengembangkan kreativitas dan pola pikir matematis melalui kegiatan problem solving (pemecahan masalah) secara berkesinambungan (simultan). Kreativitas dan pola pikir matematis ini harus dikembangkan dengan memperhatikan kemampuan berpikir setiap siswa. Aktivitas pembelajaran yang memberikan peluang bagi siswa untuk mengemukakan ide-ide atau gagasannya secara bebas akan mamacu peningkatan kemampuan berpikir yang lebih tinggi.

\section{Kesimpulan}

Berdasarkan hasil penelitian dan pembahasan yang dijabarkan mengenai penerapan model pembelajaran kooperatif tipe Group Investigation (GI) dengan menggunakan pendekatan open ended problem dalam proses pembelajaran matematika di kelas VIII $^{2}$ SMP Negeri 3 Raha telah mampu merealisasikan tujuan dan indikator pembelajaran dalam penelitian tindikan kelas ini. Terbukti dengan penerapan model pembelajaran kooperatif tipe Group Investigation (GI) dengan menggunakan 
pendekatan open ended problem pada standar kompetensi menghitung volume dan luas prisma dan limas dapat meningkatkan kemampuan representasi matematik siswa dalam setiap siklus pembelajaran.

Dalam penelitian ini, selain mampu menjawab rumusan masalah, metode penelitian tindakan kelas juga berperan dalam : meningkatkan aktivitas siswa dalam diskusi kelompok, karena merasa setiap kinerja siswa dan hasil kinerja selalu terpantau; kinerja guru dapat dievaluasi sehingga dapat menjadi pengajar yang lebih baik dalam melaksanakan kegiatan pembelajaran, dan guru dan; siswa da guru dapat teridentifikasi dengan memberikan respon yang positif dalam model pembelajaran kooperatif tipe Group Investigation (GI) dengan menggunakan pendekatan open ended problem.

\section{Daftar Pustaka}

Agus, Suprijono. 2015. Cooperative Learning. Yogyakarta: Pustaka Belajar.

Arifin, Zainal. 2011. Membangun Kompetensi Pedagodis Guru Matematika. Jawa Timur: Penerbit Cendera Cendekia.
Arikunto, S. 2013. Prosedur Penelitian Suatu Pendekatan Praktik. Jakarta: Rineka Cipta.

Dahlan, Jarnani Afgani, Dadang Juandi. 2011. Analisis Representasi Matematik Sekolah Dasar dalam Penyelesaian Masalah Matematika Kontekstual. Jurnal Pengajaran MIPA. Volume 16 (1):128138.

Depdikbud. 2014. Peraturan Mentri Pendidikan dan Kebudayaan Republik Indonesia Nomor 103 Tahun 2014 Tentang Pembelajaran pada Pendidikan Dasar dan Menengh. Jakarta: Depdikbud.

Mulyasa. 2013. Pengembangan dan Implementasi Kurikulum 2013. Bandung: Remaja Rosda Karya.

NCTM. 2000. Principles and Standars for Schools Mathematics. Reston. VA : The National Council of Teachers of Mathematics Inc.

Sabirin. 2014. Representasi dalam Pembelajaran Matematika. Jurnal IAIN Antasari: Volume 1 (2): 33-44.

Sutikno, S. 2014. Metode dan Model Pembeajaran. Lombok: Holistika.

Tristiyati, T., \& Afriansyah, A.E. 2016. Kemampuan Pemecahan Masalah Matematis Siswa Melalui Model Pembelajaran Kooperatif Tipe Diskurs Multi Repersentasi dan Reiprocal Taeching. Jurnal Silogisme: Kajian Ilmu Matematika dan Pembelajarannya, Volume 1, 4 - 14.

Yuliawati, Fitri,dkk. 2012. Penelitian Tindakan Kelas. Yogyakarta: Pustaka Insan Madani. 